\title{
Panel Data Analysis of Profitability Determinants: Evidence from Indian Telecom Companies
}

\author{
Tasneem Khan1, Mohd Shamim¹, Jatin Goyal' \\ ${ }^{1}$ Faculty of Commerce, Aligarh Muslim University, Aligarh, India \\ ${ }^{2}$ University School of Applied Management, Punjabi University, Patiala, India \\ Email: khantasneem33@gmail.com, shamim1243@gmail.com, jatin2goyal@gmail.com
}

How to cite this paper: Khan, T., Shamim, M. and Goyal, J. (2018) Panel Data Analysis of Profitability Determinants: Evidence from Indian Telecom Companies. Theoretical Economics Letters, 8, 3581-3593. https://doi.org/10.4236/tel.2018.815220

Received: November 1, 2018

Accepted: December 9, 2018

Published: December 12, 2018

Copyright (c) 2018 by authors and Scientific Research Publishing Inc. This work is licensed under the Creative Commons Attribution International License (CC BY 4.0).

http://creativecommons.org/licenses/by/4.0/

\section{c) (i) Open Access}

\begin{abstract}
The elements determining the profitability of companies have warranted special attention over time. The levels of rising debt, increased concerns for liquidity and risks of bankruptcy have impacted the revenue of manufacturing sector companies in general and service sector companies in particular. In this study, an attempt has been made to study the financial health of companies belonging to Indian telecom industry. For this purpose, a balanced panel dataset of five Indian telecom companies listed on National Stock Exchange (NSE) has been used to examine the determinants of profitability over the period of 2004-2017. Profitability has been taken as an explained variable whereas size, leverage, liquidity, non-debt tax shield (NDTS), tangibility, growth opportunities and bankruptcy probability (Altman Z-score) have been considered as explanatory variables. The findings of the study reveal that the size and growth have a direct relationship with profitability, whereas the leverage has an inverse relationship. Tangibility, NDTS, liquidity and Z-score indicate insignificant impact on profitability.
\end{abstract}

\section{Keywords}

Profitability, Panel Data, Determinants, Telecom Companies, NSE, India

\section{Introduction}

Telecommunications industry is one of the most profitable and rapidly developing industries in the world [1]. Telecommunications is usually defined as fast-growing, capital-intensive and potentially above-average profitable sector. The telecommunications is a vibrant and important sector which has been rec- 
ognized world over as an important tool for the socio-economic development of a nation. Telecom services have been an instrument of empowerment, connecting people across the globe and increasing access. The role of dynamic, responsive and business oriented telecom sector in promoting growth is well recognized and extensively documented. The telecom sectors worldwide have made noteworthy progress in the past few years and same is true for Indian telecom sector as well. The Indian telecom sector has registered a phenomenal growth during the last decade and has emerged as a fastest growing sector of the economy. India is currently the $2^{\text {nd }}$ largest telecommunications market and has the $3^{\text {rd }}$ highest number of internet users in the world. According to the information available in the annual report of 2016-17 of Telecom Regulatory Authority of India (TRAI), India's telephone subscriber base has expanded at a CAGR of 19.22 percent, and has reached 1194.58 million over the period of 2007-2017. Indian telecom sector is the second highest revenue earner for the Government of India (GoI) after accounting for the revenues from Income-tax collections. With its present pace, the sector is expected to contribute as much as 90 percent of the government's non-tax revenue. It is one of the few sectors in India which has witnessed the most fundamental, structural and institutional reforms since 1991. The remarkable reforms and initiatives have helped the telecom industry to grow and develop at a rapid pace. Further, the government policies and regulatory framework implemented by TRAI and Department of Telecommunications (DoT) have also provided a conducive environment for the telecom service providers.

However, Indian telecom sector is going through excessive competition and there are a lot of drastic and unanticipated changes presently occurring in the sector. The profitability behavior of telecom companies has also received scant attention. Since the existence of every business organization, whether big or small, is dependent upon profitability, a careful probe into the determinants of profitability is crucially important. Profitability is the key contributing factor of success and the ways of enhancing profitability are hotly debated issues among managers and scholars. Profitability is generally regarded as an important pre-condition for long-term survival and success of a firm, and moreover, it significantly affects the firm's achievement amongst other key variables of interest. This statement can equally be referred to individual companies, branches, sectors or national economy as a whole. Only profitable economy, providing necessary internal sources of financing, can provide sustainable growth. Profitability provides overall performance of a firm and it is a useful tool for forecasting measurement of a firm's performance. It also provides realization of owners' interest, and accordingly, attractiveness to investors. Identification of the sources of variation in firm's profitability is an important research theme in economics, strategic management, accounting and finance [2].

In the literature, the researchers have made plenty of efforts to explore theoretical models which can be used to improve firms' profitability. Though there is ample literature that has sought to identify the determinants of firms' profitability 
in manufacturing sectors, yet the number of studies in service sectors is scant especially for the telecom sector. Therefore, the aim of this study is to carry out an empirical testing, using panel data methodology, to determine the firm-specific factors that affect the profitability of the companies in Indian telecom sector. While there are other macro factors as well which explain the level of firm's profitability such as economic growth, employment, innovation, and technological change, however, the focus of this study is on firm specific variables only. The major research question is which factors determine the profitability and which factor can be the essence of the high priority by both the researchers and practitioners including managers, investors, debt holders, and policy makers.

The rest of the study is divided into five sections. Section 2 describes the theoretical framework in detail and reviews the previous literature. Section 3 discusses the selection of variables, hypotheses, data collection, sample, and model specifications. The empirical and analytical results are presented in Section 4. Finally, in Section 5, the conclusions and implications of the research are presented.

\section{Literature Review}

In this section, the related literature is reviewed in order to find out the determinants of profitability. Various empirical studies have attempted to identify the determinants of firm's profitability [2] [3] [4]. Reference [5] employed panel data analysis to identify the determinants of profitability using a sample of Greek non-financial firms in the Athens stock exchange. It was found that the firm's profitability is positively affected by the determinants such as size of the firm, sales growth and investment, while it is negatively affected by leverage and level of current assets. Reference [6] investigated the profitability determinants of Australian manufacturing firms, focusing both on persistence and cyclicality of a firm's profitability over the period of 1984-1993. The study found that lagged profitability and industry affiliation are the main determinants of profitability and it showed indications that firm profitability is also characterized by cyclicality. Reference [2] employed dynamic panel model on manufacturing and service sector firms in Belgium, France, Italy, and the UK over the period of 1993-2001 to identify the profitability determinants of a firm. The research, which was based on industrial economics, strategic management, accountancy, and finance approaches, showed that while a firm's size and gearing ratio are negatively related to profitability, the market share and liquidity positively influence the firm's profitability. Reference [7] investigated the determinants of firm profitability in Japan using a sample of 2000 firms over the period of 1989-2002. The study found that profitability is positively associated with size, age, and local procurement. Reference [8] used random and fixed-effect panel regression models to analyze profit heterogeneity for 961 large Australian firms during the period of 1995-2005 and included lagged profit, productivity, size, and industry affiliation as explanatory variables. The findings of the study suggested that lagged 
profit, productivity, and size play a major role in explaining profitability, whereas the effect of industry affiliation is trivial. Reference [9], using the sample of 28 manufacturing companies for the period of 2007-2011, found that determinants of corporate governance are not correlated to the performance measures of the organization. Reference [10] identified positive relation between profitability and leverage which is in consensus with trade-off theory. The study suggested that a high profit level leads to a rise in higher debt capacity as well as accompanying tax shields.

In sum, the studies researching the determinants of profitability have identified several factors in many countries by using the different methods of study over different time periods. However, these studies do not clearly come to a consensus that which factors are the most significant in relation to the firm's profitability. In majority of the cases, it usually depends upon the nature of the industry under study. So far the Indian telecom sector is concerned, the scope of this study is restricted to include firm-specific factors only due to the limited availability of the macro-level data.

\section{Research Methodology}

\subsection{Data and Sample}

The study is based on the secondary data. The data of the sample companies has been extracted from Prowess database of Centre for Monitoring Indian Economy (CMIE). The sample used in the present study belongs to Indian telecom companies listed on the National Stock Exchange (NSE) for the period of 2004-2017. Out of the total 7 telecom companies listed in NSE, only 5 companies are taken for the analysis since these 5 companies are the service providers and the remaining 2 companies are equipment providers. The shortlisted companies are Bharti Airtel Ltd., Idea Cellular Ltd., Mahanagar Telephone Nigam Ltd., Reliance Communications Ltd. and Tata Communications Ltd.

\subsection{Variables}

\subsubsection{Dependent Variable}

Profitability: The dependent variable used in the study is profitability.

\subsubsection{Independent Variables}

The study has identified the following seven variables from the reviewed literature as a determinant of profitability.

Size: Various studies state that the magnitude of a company's profitability is significantly related to its size. It can be inferred that as the size of a company grows, it enables the company to get the benefits from economies of scale. Moreover, a larger company can diversify its assets in an easier way and could exist in a competitive market with the greatest possibility [11] [12].

Tangibility: Tangible assets are physical assets that go through a relatively long period of use in the operation of the business, such as land, buildings, machinery, and construction in progress. Tangible assets can be offered as collateral 
to creditors in case of bankruptcy. A high ratio of fixed assets to total assets provides the creditors with a high level of security since they would be able to liquidate more assets in case bankruptcy [13].

Leverage: The financial structure of a firm plays an important role in its financial performance. Financial structure, or capital structure, interpolates the proportion of debt and equity in a firm. According to the pecking order theory, the companies would prefer to firstly finance their investments by internal sources [14]. There are numerous studies that have concentrated on the impact of leverage on firm performance and profitability. Reference [15] suggests that debt level could be either helpful or hurtful to the firm's performance. Considering the helpful part, some studies like [16] support the helpfulness of debt saying that debt enables a firm to increase the production capacity and boost the operational performance.

Liquidity: Maintaining adequate liquidity is much more than a corporate goal and is a condition without which a firm cannot ensure the continuity of a business [17]. According to the previous studies, higher levels of liquidity in a firm could lead to agent-principal conflict [18] [19]. It is stated that managers would exploit the resources to increase their individual benefits rather than allocating resources in investment opportunities which enhances the firm's profitability. Conversely, [20] states that companies with greater levels of liquidity are more flexible in terms of providing short-term financing which could lead to a higher profitability.

Growth Opportunities: The impact of company's growth on profitability is investigated in various studies. Reference [21] found that firms could be categorized into two groups-those which grow by increasing profitability and those which leave the market because of incurring losses.

Non-Debt Tax Shields (NDTS): Non-debt tax shields are fixed tax-deductible expenses such as depreciation, depletion, amortization, research and development expenses, investment tax credit and others that act as tax shield with similar benefits to interest expenses from debt financing, and thus, lowering the probability that the firm would have to incur more debt.

Bankruptcy Probability (Altman Z-score): Bankruptcy probability measures the degree of financial distress, which indicates that financially secure firms are not subject to significant financial distress than other firms. Altman's [22] Z-score model is an indicator of bankruptcy likelihood. Altman combined a variety of financial ratios into a single score that reflected the likelihood of a firm going into bankruptcy. Z-score is calculated by using five different ratios.

$$
\begin{aligned}
\text { Z-score }= & 1.2 \text { W.C./T.A. }+1.4 \text { R.E./T.A. }+3.3 \text { EBIT/T.A. } \\
& +0.6 \text { M.E./B.D. }+0.99 \text { SALES/T.A. }
\end{aligned}
$$

where,

$$
\begin{aligned}
& \text { W.C. = Working Capital } \\
& \text { R.E. = Retained Earnings } \\
& \text { EBIT = Earnings Before Interest and Taxes }
\end{aligned}
$$


M.E. = Market value of Equity

B.D. = Book value of Debt

T.A. = Total Assets.

Altman (1968) states that if a firm's:

Z-score $>2.99=$ Non bankruptcy area

Z-score $<1.81=$ Bankruptcy area

Z-score $>1.81$ and $<2.99=$ Gray area.

The measurement of other variables used in the study is shown in Table 1.

\subsection{Hypotheses}

As per the reviewed literature, the following null hypotheses have been stated:

- $H 1_{0}$ : There is no relationship between Leverage and Profitability of sample companies.

- $H 2_{0}$ : There is no relationship between Tangibility and Profitability of sample companies.

- $H 3_{0}$ : There is no relationship between Size and Profitability of sample companies.

- $H 4_{0}$ : There is no relationship between Growth and Profitability of sample companies.

- $H 5_{0}$ : There is no relationship between Liquidity and Profitability of sample companies.

- $H 6_{0}$ : There is no relationship between NDTS and Profitability of sample companies

- $\quad H 7_{0}$ : There is no relationship between Z-score and Profitability of sample companies.

\subsection{Model Specification}

This study utilizes the econometrics analysis using static panel data that combines the features of time-series and cross-sectional data. Panel data analysis notation differentiates this model from time-series or cross-sectional analysis by double sub-script on its variables. One sub-script represents the cross-section unit that is firm, sectors, countries etc., while the other sub-script denotes the

Table 1. Measurement of variables.

\begin{tabular}{cc}
\hline Variables & Measurement \\
\hline Profitability (PROF) & EBIT/Total Assets \\
Tangibility (TANG) & Fixed Assets/Total Assets \\
Leverage (LEV) & Total Debt/Total Assets \\
Liquidity (LIQ) & Current Assets/Current Liabilities \\
Firm size (SIZE) & Natural log of Total Assets \\
Growth Opportunities (GROW) & Market Value/Book Value \\
Non-Debt Tax Shield (NDTS) & Depreciation/Total Assets
\end{tabular}


time. Panel data allows controlling for variables which we cannot observe or measure or for variable that changes over time and not across entities, and therefore, this approach has advantages compared to the cross-sectional approach often used in financial research. In addition, by using panel data, it is possible to include time-effects as well to control for individual heterogeneity, which is captured by firm specific fixed or random effects components that leads to biased results when neglected in cross-section or time-series estimations [23].

There are several reasons why panel data approach is employed in this study. The first and the key reason is its efficiency in controlling for heterogeneity. In the framework of panel data analysis, firms are considered heterogeneous, while in time-series and cross-sectional analyses it is not the case and this issue might result in biases. The second reason of using panel data approach is that it provides both higher variations in data sets and less multicollinearity among the variables. Simultaneously, due to higher observations, they are associated with more degrees of freedom.

There are three main models that can be used to estimate the regression equation in panel data-pooled model, random effects (RE) model and fixed effects (FE) model. In order to decide which model to choose, there is a need to consider the properties of the data as well as the results of tests. Pooled regression model is one type of model that has constant coefficients, implying to both intercepts and slopes. For this model, researchers can pool all of the data and can run an ordinary least squares (OLS) regression model with no assumption on individual differences. The FE model takes into consideration the individuality of each firm or cross section unit included in the sample by allowing the intercept to vary for each firm while assuming that the slope coefficient are constant across firms. FE model is only used when it is important to analyze the impact of variables that vary over time. FE model explores the relationship between predictor and outcome variables within an entity (country, person, company, etc.). Each entity has its own individual characteristics that may or may not influence the predictor variables (e.g. being a male or female could influence the opinion towards a certain issue; or the political system of a particular country could have some effect on trade or GDP; or the business practices of a company may influence its stock price, etc.).

While using FE model, it is assumed that something within the individual may impact or bias the predictor or outcome variables and it needs to be controlled for this. This is the rationale behind the assumption of the correlation between entity's error term and predictor variables. FE model removes the effect of those time-invariant characteristics so as to assess the net effect of the predictors on the outcome variable.

On the other hand, in the RE model, the individual effects are randomly distributed across the cross-sectional units; and in order to capture the individual effects, the regression model is specified with an intercept term representing an overall constant term. RE model assumes that the entity's error term is not correlated with the predictors which allows for time-invariant variables to play a 
role as explanatory variables.

In RE model, the specifications for individual characteristics may or may not influence the predictor variables. The problem with this is that some variables may not be available therefore leading to omitted variable bias in the model. RE model allows to generalize the inferences beyond the sample used in the model. The rationale behind RE model is that, unlike the FE model, the variation across entities is assumed to be random and uncorrelated with the predictor or independent variables included in the model [24].

The FE model is an appropriate specification if the sample size is focusing on a specific set of $\mathrm{N}$ firms (e.g. when the sample comprises all the stocks traded on a particular exchange). The RE model is an appropriate specification if the sample size is drawn randomly from large population [23]. In line with the objectives, the FE model with vce (robust) turns out to be more appropriate for the static panel estimation as pooled OLS and RE model got rejected as per the test assumptions.

To estimate the relationship between the profitability and its determinants for the companies of Indian telecom sector, the used static panel model is given as:

$$
\begin{aligned}
\text { PROF }_{i t}= & \beta_{0}+\beta_{1} L E V_{i t}+\beta_{2} \text { TANG }_{i t}+\beta_{3} N D T S_{i t}+\beta_{4} L I Q_{i t} \\
& +\beta_{5} \text { SIZE }_{i t}+\beta_{6} \text { SROW }_{i t}+\beta_{7} Z S C_{i t}+\varepsilon_{i t}
\end{aligned}
$$

Here $i$ represents the companies; $t$ represents the time; $\beta_{0}$ stands for model constant; $\beta_{i}$ states the co-efficient of independent variables and $\varepsilon_{i t}$ represents the error term, which is assumed to have a normal distribution.

\section{Empirical Results}

\subsection{Descriptive Statistics}

Table 2 presents the descriptive statistics of variables used in the study. From the observation of the descriptive statistics, it can be concluded that profitability of telecom companies is unstable, since the standard deviation is akin to the mean. The independent variables namely leverage, tangibility, size, and non-debt

Table 2. Descriptive statistics.

\begin{tabular}{cccccc}
\hline Variable & No. of Observations & Mean & Std. Dev. & Min & Max \\
\hline PROF & 70 & 0.11 & 0.098 & -0.1795158 & 0.448 \\
LEV & 70 & 0.494 & 0.351 & -0.597556 & 1.310 \\
TANG & 70 & 0.556 & 0.276 & 0.0026816 & 1.880 \\
LIQ & 70 & 0.959 & 1.149 & 0.0297619 & 9.439 \\
SIZE & 70 & 10.159 & 0.983 & 8.225 & 12.138 \\
GROW & 70 & 13.733 & 27.762 & -29.87968 & 126.892 \\
NDTS & 70 & 0.054 & 0.029 & 0.000178 & 0.187 \\
ZSC & 70 & 48.652 & 138.474 & -0.4785135 & 819.451 \\
\hline
\end{tabular}

Source: Author's calculations. 
tax shield are not volatile because standard deviation is below the mean while liquidity, growth and $\mathrm{Z}$-score are highly volatile as the standard deviation is above the mean.

\subsection{Pair-Wise Correlation Analysis}

Pearson's correlation coefficient matrix is shown in Table 3.

\subsection{Analysis of Multicollinearity}

The variance inflation factor (VIF) is a test of multicollinearity which measures the relationship of all explanatory variables. It is essential to check for multicollinearity between the independent variables before running the panel regression technique. It explains how much the variance of a coefficient is inflated due to linear dependence with other explanatory variables. When the VIF is lesser, multicollinearity between explanatory variables is also less and the usual rule of thumb is that any variable with a VIF greater than 10 is a matter of concern [25]. In this study, the VIF values of the variables are within the limits prescribed. Table 4 shows the collinearity statistics of the variables.

Table 3. Pair-wise correlation matrix.

\begin{tabular}{lccccccc}
\hline Variables & $(1)$ & $(2)$ & $(3)$ & $(4)$ & $(5)$ & $(6)$ & $(7)$ \\
\hline 1) LEV & 1.000 & & & & & & \\
2) TANG & -0.031 & 1.000 & & & & & \\
3) LIQ & -0.028 & -0.213 & 1.000 & & & & \\
4) SIZE & $0.311^{*}$ & $0.265^{*}$ & -0.034 & 1.000 & & \\
5) GROW & -0.106 & 0.068 & 0.134 & -0.021 & 1.000 & \\
6) NDTS & 0.043 & $0.907^{*}$ & $-0.245^{*}$ & $0.248^{*}$ & 0.075 & 1.000 & \\
7) ZSC & $-0.429^{*}$ & 0.024 & $0.275^{*}$ & -0.091 & 0.205 & 0.045 & 1.000 \\
\hline
\end{tabular}

${ }^{*}$ Significant at the $5 \%$ level. Source: Author's calculations.

Table 4. Collinearity statistics: Tolerance test and variance inflation factor (VIF).

\begin{tabular}{ccc}
\hline Variable & VIF & $1 / \mathrm{VIF}$ \\
\hline NDTS & 6.10 & 0.163804 \\
TANG & 6.05 & 0.165323 \\
LEV & 1.46 & 0.685835 \\
ZSC & 1.42 & 0.701978 \\
SIZE & 1.22 & 0.823028 \\
LIQ & 1.20 & 0.830497 \\
GROW & 1.06 & 0.941492 \\
\hline
\end{tabular}

Source: Author's calculations. 


\subsection{Testing for Heteroscedasticity}

Heteroscedasticity occurs when the error variance differs across observations. In econometrics the measure used for spread is the variance and therefore heteroscedasticity is the consequence of unequal spread. An equal variance means that the disturbances are homoscedastic. A modified Wald-statistic test or Breusch-pagan (BP-LM) test is used to detect the existence of heteroscedasticity in the residuals of fixed effect regression [24]. Therefore, the model applied in this study accounts for heteroscedasticity.

\subsection{Estimation Results}

Table 5 shows the results of the proposed model. The estimation of these kinds of models allows to capture the existing heterogeneity among companies, corresponding to fixed elements for each company throughout the period or random elements for each company. The results of F-test confirm that the FE model is appropriate in explaining the determinants of profitability. On the other hand, the BP-LM test indicates that RE model is suitable in explaining the profitability of telecom companies and the OLS regression is not suitable way to carry out the estimation of the profitability and its determinants.

The results of Sargen-Hansen (SH) statistics (Xtoverid), which compares the FE and RE models, prove that the resulting estimator of FE model presented in

Table 5. Panel regression results. Dependent variable: Profitability.

\begin{tabular}{|c|c|c|}
\hline Independent Variables & Fixed Effects & Robust Standard Error \\
\hline LEV & $-0.142^{\star \star}$ & 0.0470 \\
\hline TANG & -0.199 & 0.171 \\
\hline LIQ & -0.0151 & 0.00724 \\
\hline SIZE & $0.0130^{*}$ & 0.00564 \\
\hline GROW & $0.000710^{*}$ & 0.000301 \\
\hline NDTS & 0.933 & 1.364 \\
\hline ZSC & -0.000131 & $6.65 e-05$ \\
\hline Constant & $0.123^{*}$ & 0.0505 \\
\hline Observations & \multicolumn{2}{|c|}{70} \\
\hline Number of Cross-Sections & \multicolumn{2}{|c|}{5} \\
\hline Number of Time-Periods & \multicolumn{2}{|c|}{14} \\
\hline R-squared & \multicolumn{2}{|c|}{0.262} \\
\hline Country FE & \multicolumn{2}{|c|}{ YES } \\
\hline Time FE & \multicolumn{2}{|c|}{ NO } \\
\hline F-test & \multicolumn{2}{|c|}{0.0018} \\
\hline L.M. test & \multicolumn{2}{|c|}{ F.E } \\
\hline S.H. test & \multicolumn{2}{|c|}{ F.E } \\
\hline
\end{tabular}

${ }^{* *} \mathrm{p}<0.01,{ }^{* *} \mathrm{p}<0.05,{ }^{*} \mathrm{p}<0.1$. Source: Author's calculations. 
Table 5 is more consistent than the estimator of RE model. In this case, the Hausaman test doesn't support the robust option in STATA because of the presence of heteroscedasticity in the data. Heteroscedasticity and serial correlation are two main problems in the regression analysis and give biased results [26]. In order to have unbiased results the SH statistics is used. The SH test concludes that the FE model is most appropriate model in explaining the determinants of profitability.

The estimated coefficient of LEV turns out to be negative and statistically significant, and thus associating high debt levels with lower profitability with the implication that the companies in Indian telecom sector are following pecking order theory [14]. The SIZE and GROW turn out to be positive and statistically significant. It suggests that larger firms enjoy higher profits as compared to the smaller ones. The remaining variables viz. LIQ, NDTS, TANG and ZSC have no influence on profitability. The sample companies do not use NDTS as a substitute for debt-tax shields.

\section{Discussion and Conclusion}

Maintaining profitability of any sector is very important not only in the view of the objective of shareholders, but also in the prospective of financial system stability of the economy. This study has attempted to identify the determinants of profitability for the companies belonging to Indian telecom sector. The study uses the FE panel data model on the data set of five listed telecom companies listed in NSE during the period 2004-2017. Results of the study are similar to the study carried by [27]. The positive relationship between size and profitability enables the study to conclude that larger firms have the opportunity to use scale economies to reduce the overall cost, and therefore to increase the profitability as well. The similar findings have been reported by [5] and [28].

The results further show that the profitability is negatively associated with leverage. This is in accordance with the findings of [28] [29] and [30]. These studies argue that the companies should use more internal funds for further expansion and that the profitable firms should borrow less and try to accumulate sufficient internal funds to meet their financial needs. The study also implies that growth is an indispensable factor to ensure profitability. The empirical studies have proved it that a large number of the firms are bankrupt not because they are not profitable but they do not have growth prospects. With respect to the other variables of the study viz. Tangibility, Liquidity, NDTS and Z-score, the empirical results stated that these variables have no influence on profitability.

\section{Conflicts of Interest}

The authors declare no conflicts of interest regarding the publication of this paper.

\section{References}

[1] KPMG (2009) The Indian Telecom Success Story. https://www.kpmg.de/docs/The_Indian_Telecom_Success_Story.pdf 
[2] Goddard, J., Tavakoli, M. and Wilson, J.O. (2005) Determinants of Profitability in European Manufacturing and Services: Evidence from a Dynamic Panel Model. Applied Financial Economics, 15, 1269-1282. https://doi.org/10.1080/09603100500387139

[3] Adams, M. and Buckle, M. (2003) The Determinants of Corporate Financial Performance in the Bermuda Insurance Market. Applied Financial Economics, 13, 133-143. https://doi.org/10.1080/09603100210105030

[4] Phillips, P.A. and Sipahioglu, M.A. (2004) Performance Implications of Capital Structure: Evidence from Quoted UK Organisations with Hotel Interests. The Service Industries Journal, 24, 31-51. https://doi.org/10.1080/0264206042000276829

[5] Asimakopoulos, I., Samitas, A. and Papadogonas, T. (2009) Firm-Specific and Economy Wide Determinants of Firm Profitability: Greek Evidence Using Panel Data. Managerial Finance, 35, 930-939. https://doi.org/10.1108/03074350910993818

[6] McDonald, J.T. (1999) The Determinants of Firm Profitability in Australian Manufacturing. Economic Record, 75, 115-126.

https://doi.org/10.1111/j.1475-4932.1999.tb02440.x

[7] Ito, K. and Fukao, K. (2010) Determinants of the Profitability of Japanese Manufacturing Affiliates in China and Other Regions: Does Localisation of Procurement, Sales and Management Matter? The World Economy, 33, 1639-1671. https://doi.org/10.1111/j.1467-9701.2009.01236.x

[8] Stierwald, A. (2010) The Causes of Profit Heterogeneity in Large Australian Firms. Melbourne Institute Working Paper No. 7/10. https://doi.org/10.2139/ssrn.1632803

[9] Velnampy, T. and Kajananthan, R. (2013) Cash Position and Profitability of Telecommunication Sector in Sri Lanka. Greener Journal of Social Sciences, 3, 324-333. https://doi.org/10.15580/GJSS.2013.6.052113626

[10] Iqbal, A., Hameed, I. and Ramzan, N. (2012) The Impact of Debt Capacity on Firm's Growth. American Journal of Scientific Research, 59, 109-115.

[11] Hardwick, P. (1997) Measuring Cost Inefficiency in the UK Life Insurance Industry. Applied Financial Economics, 7, 37-44. https://doi.org/10.1080/096031097333835

[12] Gschwandtner, A. (2005) Profit Persistence in the "Very" Long Run: Evidence from Survivors and Exiters. Applied Economics, 37, 793-806. https://doi.org/10.1080/0003684042000337406

[13] Baker, H.K. and Martin, G.S. (2011) Capital Structure and Corporate Financing Decisions: Theory, Evidence, and Practice (Vol. 15). John Wiley \& Sons, Hoboken. https://doi.org/10.1002/9781118266250

[14] Myers, S.C. and Majluf, N.S. (1984) Corporate Financing and Investment Decisions When Firms Have Information That Investors Do Not Have. Journal of Financial Economics, 13, 187-221. https://doi.org/10.1016/0304-405X(84)90023-0

[15] Campello, M. (2006) Debt Financing: Does It Boost or Hurt Firm Performance in Product Markets? Journal of Financial Economics, 82, 135-172. https://doi.org/10.1016/j.jfineco.2005.04.001

[16] Maksimovic, V. (1990) Product Market Imperfections and Loan Commitments. The Journal of Finance, 45, 1641-1653. https://doi.org/10.1111/j.1540-6261.1990.tb03733.x

[17] Shim, J.K. and Siegel, J.G. (1997) Financial Management for Nonprofits: The Complete Guide to Maximizing Resources and Managing Assets. Irwin Professional Pub.

[18] Fama, E.F. and Jensen, M.C. (1983) Agency Problems and Residual Claims. The 
Journal of Law and Economics, 26, 327-349. https://doi.org/10.1086/467038

[19] Myers, S.C. and Rajan, R.G. (1998) The Paradox of Liquidity. The Quarterly Journal of Economics, 113, 733-771. https://doi.org/10.1162/003355398555739

[20] Deloof, M. (2003) Does Working Capital Management Affect Profitability of Belgian Firms? Journal of Business Finance \& Accounting, 30, 573-588. https://doi.org/10.1111/1468-5957.00008

[21] Jovanovic, B. (1982) Selection and the Evolution of Industry. Econometrica: Journal of the Econometric Society, 50, 649-670. https://doi.org/10.2307/1912606

[22] Altman, E.I. (1968) Financial Ratios, Discriminant Analysis and the Prediction of Corporate Bankruptcy. The Journal of Finance, 23, 589-609. https://doi.org/10.1111/j.1540-6261.1968.tb00843.x

[23] Baltagi, B. (2008) Econometric Analysis of Panel Data. John Wiley \& Sons, Hoboken.

[24] Greene, W.H. (2003) Econometric Analysis. Pearson Education, London.

[25] Gujarati, D.N. (2009) Basic Econometrics. McGraw-Hill Education, New York.

[26] Gujarati, D.N. and Porter, D. (2009) Basic Econometrics. McGraw-Hill International Edition.

[27] Sivathaasan, N., Tharanika, R., Sinthuja, M. and Hanitha, V. (2013) Factors Determining Profitability: A Study of Selected Manufacturing Companies Listed on Colombo Stock Exchange in Sri Lanka. European Journal of Business and Management, 5, 99-108.

[28] Nunes, P.J.M., Serrasqueiro, Z.M. and Sequeira, T.N. (2009) Profitability in Portuguese Service Industries: A Panel Data Approach. The Service Industries Journal, 29, 693-707. https://doi.org/10.1080/02642060902720188

[29] Bancel, F. and Mittoo, U.R. (2004) Cross-Country Determinants of Capital Structure Choice: A Survey of European Firms. Financial Management, 33, 103-132.

[30] Antoniou, A., Guney, Y. and Paudyal, K. (2008) The Determinants of Capital Structure: Capital Market-Oriented versus Bank-Oriented Institutions. Journal of Financial and Quantitative Analysis, 43, 59-92. https://doi.org/10.1017/S0022109000002751 